\title{
FACTORS AFFECTING THE PERFORMANCE OF HORIZONTAL FLOW CONSTRUCTED WETLAND VEGETATED WITH CYPRUS PAPYRUS FOR MUNICIPAL WASTEWATER TREATMENT
}

\author{
Abou-Elela, Sohair, I. ${ }^{(1)}$; Elekhnawy, M. A. ${ }^{(2)}$; Khalil, M. T. $^{(3)}$; \\ Hellal, M. S. ${ }^{(1)}$ and Ibrahim, M. A \\ 1) National Research Center 2) Holding Company for Water and Wastewater \\ 3) Faculty of Science, Ain Shams University
}

\begin{abstract}
The impact of hydraulic loading rate (HLR) and hydraulic retention time (HRT) on the bioremediation of municipal wastewater using a horizontal flow constructed wetland (HFCW) vegetated with Cyprus papyrus was investigated. Three different HLRs were applied with values of $0.18,0.10$ and $0.07 \mathrm{~m}^{3} / \mathrm{m}^{2}$.d with corresponding HRT of $1.8,3.2$ and 4.7 days. The flow rate was $8.3 \mathrm{~m}^{3} / \mathrm{d}$ and the average organic loading rate was $0.037 \mathrm{~kg} \mathrm{BOD} / \mathrm{m}^{3} / \mathrm{d}$. Results showed that the performance of HFCW is linearly affected by decreasing HLR and increasing the HRT. The remediation for the heights HRT (4.7) days and lowest HLR $\left(0.07 \mathrm{~m}^{3} / \mathrm{m}^{2} . \mathrm{d}\right)$ produced high quality effluent in terms of reduction of chemical oxygen demand (COD; 86\%), biochemical oxygen demand (BOD; 87\%) and total suspended solids (TSS; $80 \%$ ) as well satisfactory nutrient removal. Also, removal of 2-3 logs of bacterial indicators was achieved. The dry biomass of Cyprus papyrus was $7.7 \mathrm{~kg} / \mathrm{m}^{2}$. Moreover, Cyprus papyrus plant proved to be very efficient in nitrification processes due to high diversity of the roots that increase the treatment surface area.

Keywords: Constructed wetland, horizontal flow, wastewater, treatment, hydraulic loading rate, hydraulic retention time, Cyprus papyrus.
\end{abstract}


J. Environ. Sci.

Institute of Environmental Studies and Research - Ain Shams University

\section{INTRODUCTION}

The shortage of water supplies is emerging as a critical issue for the future development of Egypt. Poor sanitation in Egypt is part of this problem especially in rural areas, villages and small communities where only 15\% are served by wastewater treatment plants (Abou-Elela and Hellal, 2012). Conventional wastewater treatment plants involve large capital investments and operating costs. These systems are not suitable solutions for rural communities and villages (Abou-Elela et al., 2013). Given the need to seek alternative solutions to conventional systems, priority has been given to those technologies which have a minimum or null energy cost, simple operational and maintenance procedures and high treatment efficiency. During the last 35-40 years, considerable interest has been expressed in the potential use of a variety of natural biological systems for effective purification of polluted waters (Guimaraes et al., 2010). Constructed wetlands (CW) are described as a simple and low-cost domestic water remediation systems (EPA, 2004) and are reported to be capable of removing contaminants including metals, organic and inorganic matters as well as pathogens from different wastewaters (Choudhary et al., 2011). Recently, Abou-Elela et al., (2013) discussed the application of constructed wetlands for wastewater treatment in small communities and concluded that a high percentage reduction of organic load, ammonium ion, and total phosphorus could be achieved even when the system was operated at short detention time. The use of CWs with horizontal flow is increasing around the world for domestic wastewater treatment (Liu et al., 2005). Horizontal flow constructed wetlands (HFCW) are an alternative 
option for secondary treatment prior to land application (Tanner et al., 2012). They are well suited to decentralized applications as they are requiring no mechanical components or external energy supply and have relatively long residence times. Furthermore, they are effective in removing biochemical oxygen demand (BOD), chemical oxygen demand (COD), total suspended solids (TSS), total and fecal coliform, (Solano et al., 2004). However, nitrogen and phosphate removal is limited (Abou-Elela et al., 2014). The performance of HFCW is affected by many factors such as surface area, hydraulic loading rates (HLR), hydraulic retention time (HRT), type of vegetation, type of substrate, influent pollutant concentrations and the local environment (Trang et al., 2010). The plants growing in CWs are the most obvious visual characteristic of the systems. The plants used to stabilize the bed surface, increase porosity throughout the wetland volume, adsorb and store plant nutrients, prevent channelized flow and give the wetland a nice appearance (Abou-Elela and Hellal, 2012). There are many types of plants that are used as microphytes in constructed wetland, such as Cyprus papyrus, Canna, Phragmits and Typha. Cyprus papyrus spp. and other species of plants were studied by Abou-Elela et al. (2014) in a HFCW pilot plant. They reported that Cyprus papyrus was effective in nitrogen and phosphorus uptake and the removal of total coliforms, fecal coliforms and E. coli.

Also, there is a correlation between the hydraulic parameters and pollutants removal from HFCWs. For instance lower HLRs or longer HRTs typically result in better pollutant removal. Weerakoon et al., (2013) reported that the most efficient pollutant removal can be accomplished within a 4-15 days HRT. In pilot studies carried out on HFCW, Tawfic (2003) evaluated the 
remediation efficiency under conditions of less than 1 day and 4 days HRT and concluded that the performance of the studied aquatic species varies in narrow ranges of $29 \%$ and $37 \%$ under conditions of hydraulic retention below one day, while high rates of remediation $(75-85 \%)$ where attainable with four days retention time. Although in the great majority of studies on the effect of HLR and HRT on removal efficiency of HFCW systems is statistically proven, however, studying the application of different HLR and HRT at the same time on HFCW was not well investigated (Çakir et al., 2015). In this study, the performance of a pilot plant HFCW vegetated with Cyprus papyrus for wastewater treatment was evaluated at different HLR, HRT and organic loading rate (OLR).

\section{MATERIALS AND METHODS}

In order to achieve the objectives of this study, a pilot plant horizontal flow constructed wetland (HFCW) planted with Cyprus papyrus was designed, constructed and put into operation within the vicinity of a wastewater treatment plant (WWTP). The treatment basin was fed continuously with real settled municipal wastewater.

\section{Pilot plant description}

The total surface area of the HFCW was $115.5 \mathrm{~m}^{2}$ with a depth of $0.85 \mathrm{~m}$ and $0.7 \%$ slope along the basin. It was filled with $20-25 \mathrm{~mm}$ diameter gravel in the entire unit except one meter from the beginning. The end of the basin was filled with $40-80 \mathrm{~mm}$ gravel to prevent clogging. Figure (1) shows a schematic diagram of the HFCW. 
Final Treated Effluent

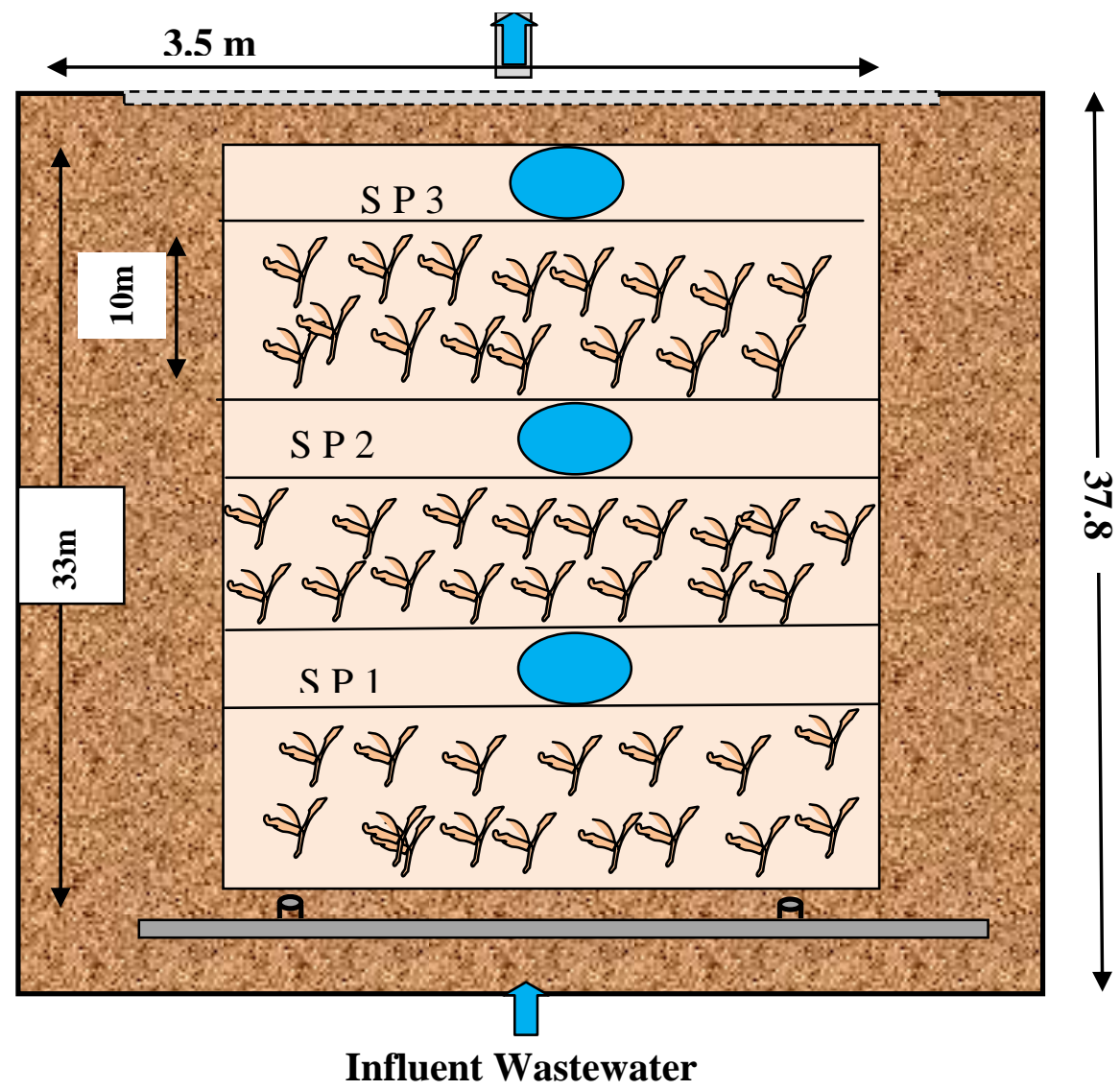

Figure (1): A schematic diagram of the HFCW 
J. Environ. Sci.

Institute of Environmental Studies and Research - Ain Shams University

Table (1): Operating conditions and design criteria of HFCW

\begin{tabular}{|l|c|c|c|}
\hline \multirow{2}{*}{\multicolumn{1}{|c|}{ Design Parameters }} & \multicolumn{3}{c|}{ Basin } \\
\cline { 2 - 4 } & S P 1 & S P 2 & S P 3 \\
\hline Flow rate & $13 \mathrm{~m}$ & $23 \mathrm{~m}$ & $33 \mathrm{~m}$ \\
\hline Length & \multicolumn{3}{|c|}{$3.5 \mathrm{~m} \mathrm{~m}^{3} /$ day } \\
\hline Width & \multicolumn{3}{|c|}{$0.85 \mathrm{~m}$} \\
\hline Depth & $40 \%$ \\
\hline Porosity & $45.5 \mathrm{~m}^{2}$ & $80.5 \mathrm{~m}^{2}$ & $115.5 \mathrm{~m}^{2}$ \\
\hline Surface area & $38.7 \mathrm{~m}^{3}$ & $68.4 \mathrm{~m}^{3}$ & $98.2 \mathrm{~m}^{3}$ \\
\hline Total volume & $15.5 \mathrm{~m}^{3}$ & $27.3 \mathrm{~m}^{3}$ & $39.3 \mathrm{~m}^{3}$ \\
\hline Effective volume & $1.8 \mathrm{days}^{3} 3.2 \mathrm{days}_{1}$ & $4.7 \mathrm{days}$ \\
\hline HRT & 0.18 & 0.1 & 0.07 \\
\hline HLR $\mathrm{m}^{3} / \mathrm{m}^{2} . \mathrm{d}$ & \multicolumn{3}{|c|}{$0.037 \mathrm{~kg} \mathrm{BOD} / \mathrm{m}^{3} / \mathrm{d}$} \\
\hline OLR average & \multicolumn{3}{|c|}{} \\
\hline
\end{tabular}

\section{Sampling location and duration:}

Wastewater samples were collected on weekly basis from the influent and the different sampling points along the basin. Also, different parts of the plant (stem, leaves and roots) were collected on monthly basis for analysis. The samples were collected and analyzed for a duration of almost one year.

\section{Physico-chemical, biological and heavy metals analysis:}

The $\mathrm{pH}$, total dissolved solids (TDS) and temperature were measured using Thermo Scintific Orion 5 star. Chemical oxygen demand (COD), Nitrite $\left(\mathrm{NO}^{-2}\right)$ and Nitrate $\left(\mathrm{NO}^{-3}\right)$ were measured by spectrophotometer, Hach (DR 6000). Analysis of $\mathrm{N}-\mathrm{NH}^{+4}$ and $\mathrm{TKN}$ were carried out using Gerhardt Digestion and Distillation apparatus, Vapodest 10sn. Biological oxygen demand $\left(\mathrm{BOD}_{5}\right)$, total suspended solids (TSS), total coliforms (TC), Fecal coliforms (FC) and Escherichia coli (E-coli) were determined according to 
the standard methods for water and wastewater examinations (APHA, 2012). Analysis of heavy metals namely Lead (Pb), Chromium (Cr), Nickel (Ni), Copper $(\mathrm{Cu})$, Cadmium $(\mathrm{Cd})$ and Zink $(\mathrm{Zn})$ were carried out using inductively coupled plasma-atomic emission spectrometry (ICP).

\section{RESULTS AND DISCUSSION}

Characterization of influent wastewater: Physico-chemical and biological analysis of the influent wastewater is depicted in Table (2). The results indicated a great variation in the strength of the influent wastewater. TSS was ranged from 84 to $122 \mathrm{mg} / \mathrm{l}$ with an average value of $102.4 \mathrm{mg} / \mathrm{l}$, while TDS ranged from 430 to $550 \mathrm{mg} / \mathrm{l}$. The BOD concentration ranged from 150 to $220 \mathrm{mg} / \mathrm{l}$, with an average value of $175.7 \mathrm{mg} / \mathrm{l}$. The COD ranged from 260 to $360 \mathrm{mg} / \mathrm{l}$, with an average value of $304.5 \mathrm{mg} / \mathrm{l}$. The ammonia and TKN concentrations varied from 19 to $27.1 \mathrm{mg} \mathrm{N} / 1$ and from 30.6 to $50.2 \mathrm{mg} \mathrm{N} / \mathrm{l}$, respectively. 
J. Environ. Sci.

Institute of Environmental Studies and Research - Ain Shams University

Table (2): Characterization of influent wastewater to HFCW

\begin{tabular}{|c|c|c|c|}
\hline Parameters* & Unit & Range & Mean \\
\hline $\mathrm{pH}$ & -- & $6.9-7.2$ & -- \\
\hline $\mathrm{TDS}$ & $\mathrm{mg} / \mathrm{l}$ & $430-550$ & $498 \pm 25$ \\
\hline $\mathrm{TSS}$ & $\mathrm{mg} / \mathrm{l}$ & $84-122$ & $102.4 \pm 9.2$ \\
\hline $\mathrm{BOD}$ & $\mathrm{mg} \mathrm{O}_{2} / 1$ & $150-220$ & $175.7 \pm 18$ \\
\hline $\mathrm{COD}$ & $\mathrm{mg} \mathrm{O}_{2} / 1$ & $260-360$ & $304.5 \pm 25.3$ \\
\hline $\mathrm{NH}_{3}$ & $\mathrm{mgN} / \mathrm{l}$ & $19-27.1$ & $22.8 \pm 2.5$ \\
\hline $\mathrm{TKN}^{\mathrm{mgN} / 1}$ & $30.6-50.2$ & $41 \pm 5.5$ \\
\hline $\begin{array}{c}\text { Total Coliform } \\
\text { (TC) }\end{array}$ & $\begin{array}{c}\mathrm{MPN}- \\
\text { Index/100ml }\end{array}$ & $3.6 \times 10^{5}-1.20 \times 10^{8}$ & $4.06 \times 10^{7}$ \\
\hline $\begin{array}{c}\text { Fecal Coliform } \\
\text { (FC) }\end{array}$ & $\begin{array}{c}\mathrm{MPN}- \\
\text { Index/100ml }\end{array}$ & $\begin{array}{c}5.60 \times 10^{4}- \\
1.10 \times 10^{7}\end{array}$ & $2.95 \times 10^{6}$ \\
\hline $\begin{array}{c}\mathrm{E} . \text { Coli } \\
\text { Index } / 100 \mathrm{ml}\end{array}$ & $\begin{array}{c}2.10 \times 10^{3}- \\
7.90 \times 10^{4}\end{array}$ & $2.09 \times 10^{4}$ \\
\hline
\end{tabular}

* Mean of 25 samples

Analysis of heavy metals $(\mathrm{Pb}, \mathrm{Cu}, \mathrm{Ni}, \mathrm{Cr}, \mathrm{Cd}$ and $\mathrm{Zn})$ indicated the presence of very low concentrations. This was expected since the raw wastewater used is mainly municipal wastewater. All physico-chemical analysis and bacteriological examinations of influent wastewater indicated that the wastewater used in this study is considered as a medium strength wastewater.

\section{Effect of HLR, HRT and OLR on the performance of HFCW vegetated} with Cyprus papyrus:

Performance of the HFCW at different HLRs, organic loading rates OLRs and hydraulic retention time HRT are depicted in Table (3 
Table (3): Physico-chemical characteristics of the effluents at different sampling points along the basin.

\begin{tabular}{|c|c|c|c|c|c|c|c|c|c|c|c|c|c|c|}
\hline \multirow{2}{*}{\multicolumn{2}{|c|}{ Unit }} & \multirow{2}{*}{$\begin{array}{c}\text { Raw } \\
\text { wastewater }\end{array}$} & \multicolumn{3}{|c|}{ SP 1} & \multirow{2}{*}{$\begin{array}{l}\% \\
\text { R. }\end{array}$} & \multicolumn{3}{|c|}{ S P 2} & \multirow{2}{*}{$\begin{array}{l}\% \\
\text { R. }\end{array}$} & \multicolumn{3}{|c|}{ SP 3} & \multirow{2}{*}{$\begin{array}{l}\% \\
\text { R. }\end{array}$} \\
\hline & & & Min & Max & Mean & & Min & Max & Mean & & Min & Max & Mean & \\
\hline $\mathrm{pH}$ & - & 7.2 & 6.9 & 7.7 & 7.2 & -- & 7.0 & 7.7 & 7.3 & - & 7 & 8 & 7.4 & - \\
\hline TDS & $\mathrm{mg} / \mathrm{l}$ & 498 & 400 & 600 & 527 & - & 499 & 650 & 559 & - & 512 & 685 & 601 & - \\
\hline TSS & $\mathrm{mg} / \mathrm{l}$ & 102.4 & 39 & 75 & 53 & 48.2 & 29 & 62 & 36 & 64.8 & 10 & 34 & 20 & 80.4 \\
\hline BOD & mg/ & 175.7 & 37 & 108 & 62 & 64.7 & 27 & 68 & 40 & 77.2 & 14 & 37.4 & 23 & 86.9 \\
\hline COD & $\mathrm{mg} / \mathrm{l}$ & 304.4 & 61 & 185 & 103 & 66.1 & 48 & 121 & 68 & 77.6 & 24 & 56 & 38 & 87.5 \\
\hline \multicolumn{3}{|c|}{ Operating conditions } & \multicolumn{4}{|c|}{$\begin{array}{c}\text { HLR }=0.18 \mathrm{~m}^{3} / \mathrm{m}^{2} . \mathrm{d} \\
\text { OLR }=0.094 \mathrm{~kg} \mathrm{BOD} / \mathrm{m}^{3} / \mathrm{d} \\
\text { HRT }=1.8 \text { days }\end{array}$} & \multicolumn{4}{|c|}{$\begin{array}{c}\text { HLR }=0.1 \mathrm{~m}^{3} / \mathrm{m}^{2} . \mathrm{d} \\
\text { OLR }=0.053 \mathrm{~kg} \mathrm{BOD} / \mathrm{m}^{3} / \mathrm{d} \\
\mathrm{HRT}=3.2 \mathrm{days}\end{array}$} & \multicolumn{4}{|c|}{$\begin{array}{c}\text { HLR }=0.07 \mathrm{~m}^{3} / \mathrm{m}^{2} . \mathrm{d} \\
\text { OLR }=0.037 \mathrm{~kg} \mathrm{BOD} / \mathrm{m}^{3} / \mathrm{d} \\
\mathrm{HRT}=4.7 \text { days }\end{array}$} \\
\hline $\mathrm{NH}_{3}$ & $\mathrm{mg} / \mathrm{l}$ & 22.7 & 13 & 24 & 17 & 25.1 & 8 & 18 & 13 & 42.7 & 3.2 & 12.7 & 7.1 & 68.7 \\
\hline TKN & $\mathrm{mg} / \mathrm{l}$ & 41.07 & 18 & 39.6 & 28 & 31.8 & 15 & 35 & 22 & 46.4 & 9.5 & 22.2 & 15.5 & 62.2 \\
\hline $\mathrm{NO}_{2}^{-}$ & $\mathrm{mg} / \mathrm{l}$ & 0.03 & 0.04 & 0.14 & 0.07 & - & 0.04 & 0.16 & 0.1 & - & 0.81 & 1.87 & 0.15 & - \\
\hline $\mathrm{NO}_{3}^{-}$ & $\mathrm{mg} / \mathrm{l}$ & 0.7 & 0.22 & 1.22 & 0.9 & - & 0.7 & 1.7 & 1.2 & - & 0.09 & 0.99 & 1.4 & - \\
\hline \multicolumn{3}{|c|}{ Operating conditions } & \multicolumn{4}{|c|}{$\begin{array}{c}\text { HLR }=0.18 \mathrm{~m}^{3} / \mathrm{m}^{2} . \mathrm{d} \\
\text { OLR }=0.094 \mathrm{~kg} \mathrm{BOD} / \mathrm{m}^{3} / \mathrm{d} \\
\text { HRT }=1.8 \mathrm{davs}\end{array}$} & \multicolumn{4}{|c|}{$\begin{array}{c}\text { HLR }=0.1 \mathrm{~m}^{3} / \mathrm{m}^{2} . \mathrm{d} \\
\text { OLR }=0.053 \mathrm{~kg} \mathrm{BOD} / \mathrm{m}^{3} / \mathrm{d} \\
\mathrm{HRT}=3.2 \mathrm{days}\end{array}$} & \multicolumn{4}{|c|}{$\begin{array}{c}\text { HLR }=0.07 \mathrm{~m}^{3} / \mathrm{m}^{2} . \mathrm{d} \\
\text { OLR }=0.037 \mathrm{~kg} \mathrm{BOD} / \mathrm{m}^{3} / \mathrm{d} \\
\text { HRT }=4.7 \text { davs }\end{array}$} \\
\hline
\end{tabular}

* Mean of 25 samples

Reduction of TSS, BOD and COD: Increasing the HRT from 1.8 to 3.2 days, while decreasing the HLR from 0.18 to $0.10 \mathrm{~m}^{3} / \mathrm{m}^{2}$.d improved greatly the quality of the treated effluent. The average removal of TSS increased from $48.2 \%$ at HLR $0.18 \mathrm{~m}^{3} / \mathrm{m}^{2}$.d to $64.8 \%$ at HLR $0.10 \mathrm{~m}^{3} / \mathrm{m}^{2}$.d and then reached $80.4 \%$ at HLR $0.07 \mathrm{~m}^{3} / \mathrm{m}^{2}$.d. The results obtained are in agreement with Shubiau et al, (2011). The reduction in TSS in wetlands is supported by physical processes such as filtration, sedimentation and microbial assimilation within the wetland substrate media. Further, Manios et al. (2003) listed substrate hydraulics and microbiological characteristics as the other main TSS reduction processes in a wetland system. At increased HLRs solid particles have more tendencies to escape the substrate media with increasing flow 
velocities. Similar results were also observed in other studies. Manios et al. (2003) illustrated that TSS removal depends on the type and size of the substrate media and hydraulic retention time (HRT) or HLR.

The same behavior was observed for BOD and COD removals. BOD removal value was $64.7 \%$ at HLR $0.18 \mathrm{~m}^{3} / \mathrm{m}^{2} . \mathrm{d}$ and improved to $77.2 \%$ at HLR $0.10 \mathrm{~m}^{3} / \mathrm{m}^{2}$.d and reached $86.9 \%$ at HLR $0.07 \mathrm{~m}^{3} / \mathrm{m}^{2}$.d. The average of COD reduction was $66.1 \%$ at HLR $0.18 \mathrm{~m}^{3} / \mathrm{m}^{2}$.d and increased to $77.6 \%$ at HLR $0.10 \mathrm{~m}^{3} / \mathrm{m}^{2} . \mathrm{d}$ and $87.5 \%$ at HLR $0.07 \mathrm{~m}^{3} / \mathrm{m}^{2} . \mathrm{d}$.

The drop in $\mathrm{BOD}_{5}$ and COD removal efficiencies at high HLRs can be attributed to the insufficient contact time within the system. According to Reed and Brown (1995) the $\mathrm{BOD}_{5}$ removal in a wetland system is critical below 1 day HRT and improves until HRT of about 7.5 days. The results obtained during our study gave a very high quality effluent at a HRT of 3.2 days. In addition, the COD removal efficiencies achieved in this study under different HLRs are comparable with the average results reported by Konnerup et al. (2009) using HFCW. They achieved $41 \%$ and $80 \%$ COD reduction at $0.44 \mathrm{~m}^{3} / \mathrm{m}^{2} . \mathrm{d}$ and $0.55 \mathrm{~m}^{3} / \mathrm{m}^{2}$.d HLR. Figure (2) illustrates the average removal rates of TSS, BOD and COD at different HLRs and HRTs. 


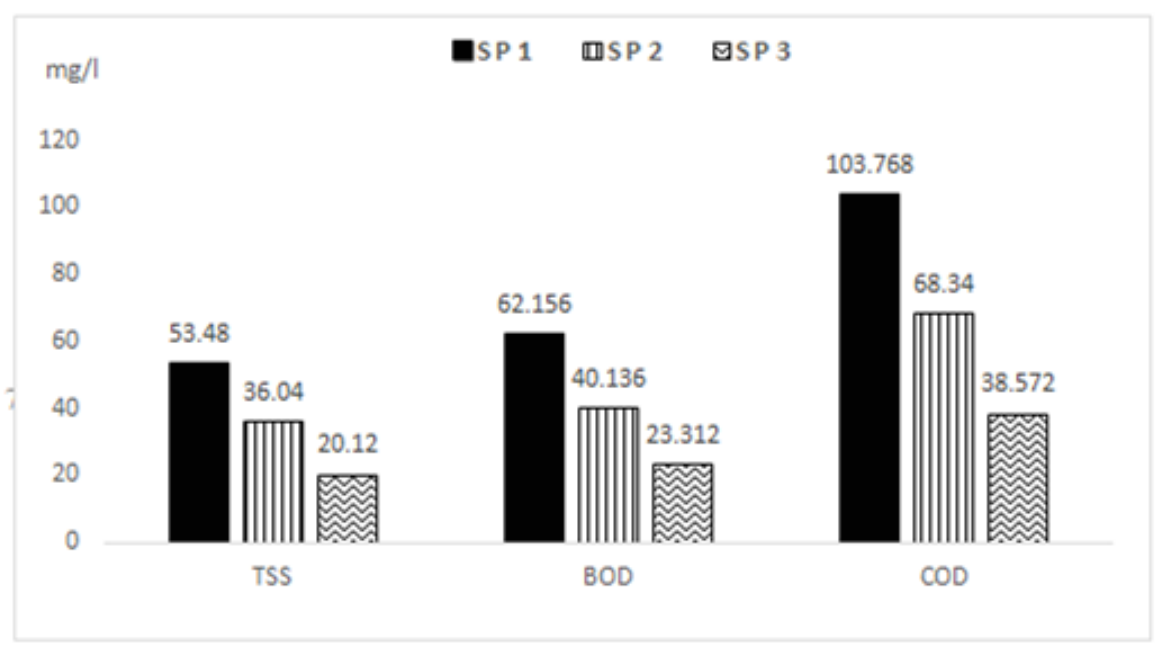

Figure (2): Variations of TSS, BOD and COD concentrations at different samples points.

TKN and ammonia removal: The results illustrated in Figure (3) indicate that by decreasing the HLR and consequently increasing HRT improves the removal rate of TKN. The average reduction of TKN reached $31.8 \%$ at $\mathrm{HRT}$ 1.8 days with a residual value of $28 \mathrm{mg} / \mathrm{l}$, then reached $46.4 \%$ at HRT 3.2 days with a residual value of $22 \mathrm{mg} / \mathrm{l}$ and finally it was $62.2 \%$ at HRT 4.7 days with a residual value of $15.5 \mathrm{mg} / \mathrm{l}$.

The same behavior was observed for $\mathrm{NH}_{3}$. Figure (4) indicates that by decreasing the HLR and consequently increasing HRT, the removal rate of $\mathrm{NH}_{3}$ has been improved. The average reduction of $\mathrm{NH}_{3}$ reached $25.1 \%$ at HLR $0.18 \mathrm{~m}^{3} / \mathrm{m}^{2}$.d with a residual value of $17 \mathrm{mg} / \mathrm{l}$, then reached $42.7 \%$ at HLR $0.10 \mathrm{~m}^{3} / \mathrm{m}^{2} . \mathrm{d}$ with a residual value of $13 \mathrm{mg} / \mathrm{l}$ and finally it was $68.7 \%$ at HLR $0.07 \mathrm{~m}^{3} / \mathrm{m}^{2} . \mathrm{d}$ with a residual value of $7.1 \mathrm{mg} / \mathrm{l}$. 

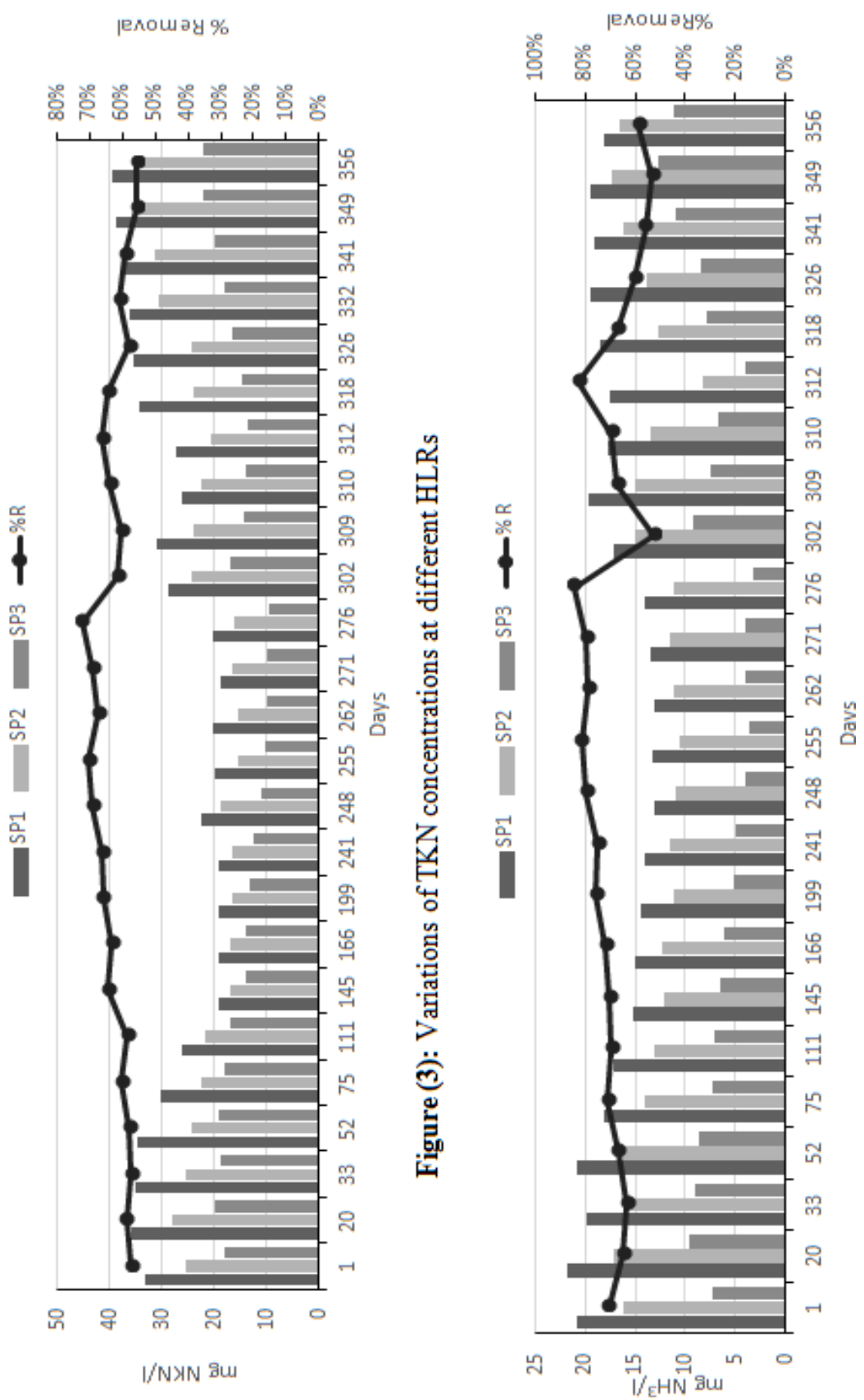
When the HLR increased, soil clogging occurred due to overfeeding and soil permeability decreased quickly to a small value (Haibo Li et al., 2012). Deterioration of nitrification was obvious caused by soil clogging, resulting in the great elevation of $\mathrm{NH}_{3}$ concentration in effluent at this condition. Correspondingly, ${ }^{3}$ average $e^{3}$ TKN ${ }^{2}$ removal efficiency decreased. The transformation and removal of nitrogen in CWs could be accomplished by ammonification (Amino acids $\rightarrow \mathrm{NH}_{4}-\mathrm{N}$ ), classical route of nitrification $\left(\mathrm{NH}_{4}-\mathrm{N} \rightarrow \mathrm{NO}_{2}-\mathrm{N} \rightarrow \mathrm{NO}_{3}-\mathrm{N}\right)$, and classical denitrification ( $\mathrm{NO}^{-}$ ${ }^{3}-\mathrm{N} \rightarrow \mathrm{NO}^{-2}-\mathrm{N} \rightarrow \mathrm{NO} \rightarrow \mathrm{N}_{2} \mathrm{O} \rightarrow \mathrm{N}_{2}$ ) (Vymazal, 2007). Nitrification is the second step of nitrogen trans-formation if the wastewater is primarily composed of organic nitrogen. However, if $\mathrm{NH}_{4}{ }^{+}-\mathrm{N}$ predominates, the nitrification process becomes the first step to convert the existing form (Saeed and Sun, 2012). The results depicted in Figure (5) showed that the ammonia removal increased with the increase of nitrification process and the decrease of HLR. Also, Cyprus papyrus plant proved to be very efficient in nitrification processes due to the high diversity of the roots that increase the treatment surface area. These results coincide with those found by Kyambadde et al. (2004). Cyprus papyrus root structures provided more microbial attachment sites, sufficient wastewater residence time, trapping and settlement of suspended particles, surface area for pollutant adsorption, uptake, assimilation in plant tissues and oxygen for organic and inorganic matter oxidation in the rhizosphere, accounting for its high treatment efficiency. In addition, Cyprus papyrus exhibited a significantly large number of adventitious roots. Nitrifying bacteria attached to Cyprus papyrus and the corresponding nitrification activities were consistent with this finding. 


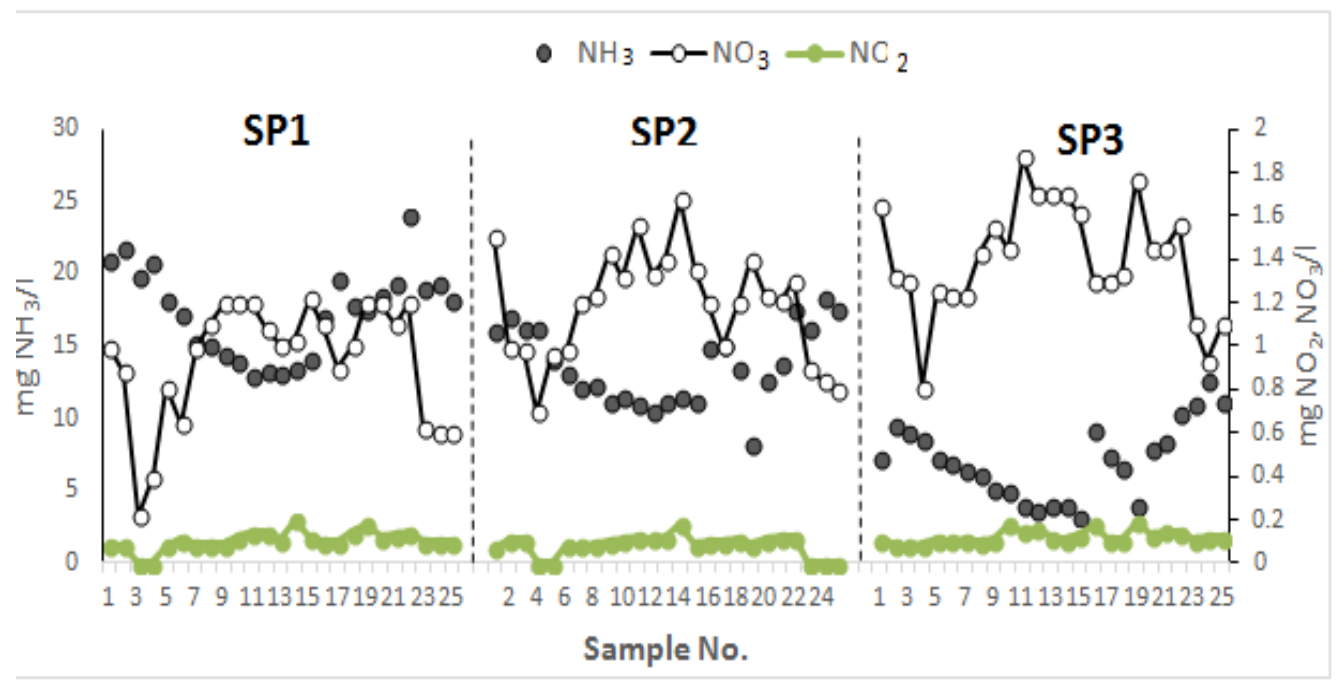

Figure (5): The relation between ammonia removal and nitrate formation at different HLR.

Microbial removal: The results depicted in Table (4) show that the removal rate of bacterial indicators has been increased as the HLR decreased and HRT increased along the basin. By increasing the HRT from 1.8 days at point (SP 1) to 3.8 days at point (SP 2), the removal of TC, FC and E.coli increased by $1.5 \operatorname{logs}, 1.4 \operatorname{logs}$ and $0.86 \log$, respectively, while the removal of TC, FC and E.Coli at HRT 4.7 days and HLR $0.07 \mathrm{~m}^{3} / \mathrm{m}^{2}$.d point (SP3) increased by 2.5 logs, $2.4 \operatorname{logs}$ and $1.0 \log$, respectively.

The results obtained can be explained on the biases that coliform removal mechanism in a constructed wetland includes physical processes; filtration, sedimentation, ultra-violet radiation, etc., chemical processes; adsorption, oxidation, die-off due to toxins and biological activities; ingestion by protozoans, release of antibiotics by plant roots and natural die-off. Further, it 
is believed that the plant coverage, hydraulic retention time and settling of microorganisms also play key roles in coliform reduction efficiency (Trang et al., 2010).

Table (4): Average bacterial counts in effluent of HFCW at (SP 1, SP 2 and SP 3) points

\begin{tabular}{|c|c|c|c|c|c|c|c|c|c|c|}
\hline \hline \multirow{2}{*}{ Parameter } & influent & \multicolumn{3}{|c|}{ (SP l)point MPN-Index/100ml } & \multicolumn{3}{|c|}{ (SP 2) point MPN-Index/100ml } & \multicolumn{3}{|c|}{ (SP 3) point MPN-Index/100ml } \\
\cline { 3 - 13 } & wastervater & Min & Max & Average & Min & Max & Average & Min & Max & Average \\
\hline \hline $\begin{array}{c}\text { Total Coliform } \\
\text { (TC) }\end{array}$ & $4.06 \times 10^{7}$ & $2 \times 10^{5}$ & $2.5 \times 10^{7}$ & $4.5 \times 10^{6}$ & $3.7 \times 10^{3}$ & $1.7 \times 10^{6}$ & $4.0 \times 10^{5}$ & $1.8 \times 10^{2}$ & $1.7 \times 10^{5}$ & $3.1 \times 10^{4}$ \\
\hline $\begin{array}{c}\text { Fecal Coliform } \\
\text { (FC) }\end{array}$ & $2.95 \times 10^{6}$ & $3.6 \times 10^{4}$ & $3.1 \times 10^{6}$ & $7.5 \times 10^{5}$ & $3.6 \times 10^{2}$ & $2.1 \times 10^{5}$ & $5.2 \times 10^{4}$ & $1.8 \times 10^{2}$ & $6.1 \times 10^{3}$ & $1.6 \times 10^{3}$ \\
\hline E. coli & $2.09 \times 10^{4}$ & $1.5 \times 10^{3}$ & $4.0 \times 10^{3}$ & $2.4 \times 10^{3}$ & $1.7 \times 10^{2}$ & $3.1 \times 10^{3}$ & $1.5 \times 10^{3}$ & $6.3 \times 10^{1}$ & $5.6 \times 10^{3}$ & $1.0 \times 10^{3}$ \\
\hline \hline
\end{tabular}

Plants uptake and biomass production: Plant harvesting must be practiced in order to remove organic matters and nutrients from the system. Since the aim of this study is to achieve the highest removal of pollutants, biomass was harvested after 12 months operation for Cyprus papyrus. The dry biomass of Cyprus papyrus was $7.7 \mathrm{~kg} / \mathrm{m}^{2}$. This biomass yield was greater than that reported for the same plant by Abou-Elela et al. (2013). They reported maximum dry biomass of $5.6 \mathrm{~kg} / \mathrm{m}^{2}$ at HLR $0.03 \mathrm{~m}^{3} / \mathrm{m}^{2} . \mathrm{d}$ and HRT 11 days. The plant nitrogen and phosphorus uptake was $116.4 \mathrm{~g} / \mathrm{m}^{2}$ and $70.2 \mathrm{~g} / \mathrm{m}^{2}$, respectively. These results are in agreement with Abou-Elela et al. (2013), who reported that nitrogen and phosphorus uptake by Cyprus papyrus was better than other plants used. 


\section{CONCOLUSION}

This study investigated the effects of HLR, HRT and OLR on the performance of HFCW vegetated with Cyprus papyrus for municipal wastewater treatment. Pollutant removal efficiencies decreased with increasing the HLR and decreasing HRT. Accordingly, HLR and HRT are a significant design parameters determining the treatment efficiency in HFCW. Results revealed that HFCW with Cyprus papyrus is capable of substantial reduction of $\mathrm{COD}, \mathrm{BOD}_{5}, \mathrm{TSS}, \mathrm{TKN}, \mathrm{NH}_{3}, \mathrm{FC}$ and TC concentrations with a good buffering capacity under HLR, 0.10 and $0.07 \mathrm{~m}^{3} / \mathrm{m}^{2} . \mathrm{d}$. The application of HLR $0.07 \mathrm{~m}^{3} / \mathrm{m}^{2}$.d and HRT of 4.7 days result in $87.5 \%, 87 \%$ and $80.4 \%$ removal of COD, BOD and TSS respectively. This makes the HFCW systems as a useful treatment alternative at places with high flow fluctuations, Furthermore the use of Cyprus papyrus proved to be very efficient in nitrification process as well as it can be used as commercial product for many industries. In addition one of the benefits of HFCW is the generation of beautiful landscape generated as a result of the presence of Cyprus papyrus plants located in the basin of treatment.

\section{REFRENCES}

Abou- Elela, S. I., and Hellal, M. S. (2012): Municipal wastewater treatment using vertical flow constructed wetlands planted with Canna, Phragmites and Cyprus. Ecological engineering, 47, 209- 213.

Abou-Elela, S. I.; Golinelli, G.; El-Tabl, A. S. and Hellal, M. S. (2014): Treatment of municipal wastewater using horizontal flow constructed wetlands in Egypt. Water Science and Technology, 69(1), 38- 47. 
Abou-Elela, S. I.; Golinielli, G.; Abou-Taleba, E. M. and Hellal, M. S. (2013): Municipal wastewater treatment in horizontal and vertical flows constructed wetlands. Ecological Engineering, 61, 460468.

APHA, American Public Health Association, (2012): Standard methods for the examination of water and wastewater, 22nd ed. United Book Press, USA.

Çakir, R., Gidirislioglu, A. and Çebi, U. (2015): A study on the effects of different hydraulic loading rates (HLR) on pollutant removal efficiency of subsurface horizontal-flow constructed wetlands used for treatment of domestic wastewaters. Journal of Environmental Management, 164, 121-128.

Choudhary, A.K., Kumar, S. and Sharma, S. (2011): Constructed wetlands: an approach for wastewater treatment. Elix. Pollut. 37, 36663672 .

EPA, (2004): Constructed Treatment Wetlands. Office of Water, 843-F-03013, 2004.

Guimaraes, B.; Simoes, P. and Marques, R. (2010): Does performance evaluation help public managers? A balanced scorecard approach in urban waste services. J. Environ. Manag. 91 (12) 2632- 2638.

Haibo, L.; Yinghua L.; Tieheng S. and Xin W. (2012): The use of a subsurface infiltration system in treating campus sewage under variable loading rates. Ecological Engineering, 38 (6) 105- 109.

Kaplan, R. and Norton, D., (1992): The balanced scorecard measures that drive performance. Harv. Bus. Rev. 70 (1), 70- 79.

Konnerup, D., Koottatep, T. and Brix, H. (2009): Treatment of domestic wastewater in tropical, subsurface flow constructed wetlands planted with Canna and Heliconia. Ecological engineering, 35(2), 248-257.

Kyambadde, J., Kansiime, F., Gumaelius, L. and Dalhammar, G. (2004): A comparative study of Cyprus papyrus and Miscanthidium violaceum-based constructed wetlands for wastewater treatment in a tropical climate. Water Research, 38(2). 475- 485. 
Liu, W.; Dahab, M. F. and Surampalli, R. Y. (2005): Nitrogen transformations modeling in subsurface-flow constructed wetlands. Water environment research, 77(3) 246-258.

Manios, T.; Stentiford, E. I., and Millner, P. (2003): Removal of total suspended solids from wastewater in constructed horizontal flow subsurface wetlands. Journal Environmental Science and Health, Part A, 38(6) 1073- 1085.

Reed, S. C. and Brown, D. (1995): Subsurface flow wetlands - a performance evaluation. Water environment research, 67(2), 244-248.

Saeed, T. and Sun, G. (2012): A review on nitrogen and organics removal mechanisms in subsurface flow constructed wetlands: dependency on environmental parameters, operating conditions and supporting media. Journal Environmental Management, 112, 429- 448.

Solano, M. L.; Soriano, P. and Ciria, M. P. (2004): Constructed wetlands as a sustainable solution for wastewater treatment in small villages. Biosystems Engineering, 87(1) 109-118.

Tanner, C. C.; Sukias, J. P.; Headley, T. R., Yates; C. R., and Stott, R. (2012): Constructed wetlands and denitrifying bioreactors for on-site and decentralised wastewater treatment: comparison of five alternative configurations. Ecological Engineering, 42, 112-123.

Tawfic, T. A. (2003): Effective natural wastewater treatment systems in rural areas of Egypt. In The 4th International Conference \& Exhibition for Environmental Technologies, Management \& Funding" The Gateway to Profitable Environmental Compliance" Cairo International Conference Center (Vol. 30, pp. 02-09).

Trang, N. T. D., Konnerup, D.; Schierup, H. H.; Chiem, N. H. and Brix, H. (2010): Kinetics of pollutant removal from domestic wastewater in a tropical horizontal subsurface flow constructed wetland system: effects of hydraulic loading rate. Ecological engineering, 36(4), 527-535.

Vymazal, J. (2007): Removal of nutrients in various types of constructed wetlands. Science of the Total Environment, 380 (1) 48-65. 
Weerakoon, M.P.R.; Jinadasa, K.B.S.N.; Herath, G.B.B.; M.I.M. Mowjood and Van Bruggen, J.J.A. (2013): Impact of the hydraulic loading rate on pollutants removal in tropical horizontal subsurface flow constructed wetlands. Ecol. Eng. 61, 154- 160.

Wu, S., Austin, D., Liu, L. and Dong, R. (2011): Performance of integrated household constructed wetland for domestic wastewater treatment in rural areas. Ecological Engineering, 37(6) 948-954.

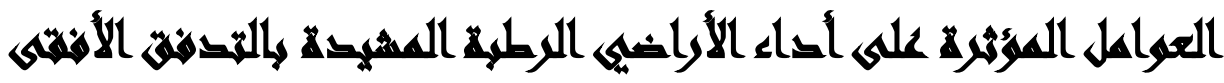

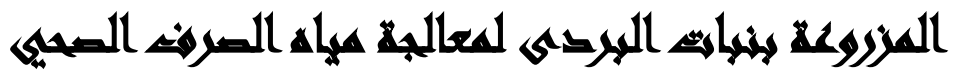

[1]

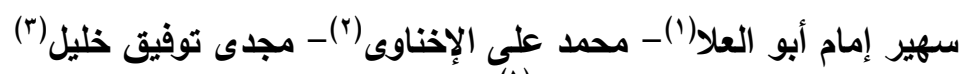
محمد سعد هلال (') - محمد علي الإخناوي إبراهيم

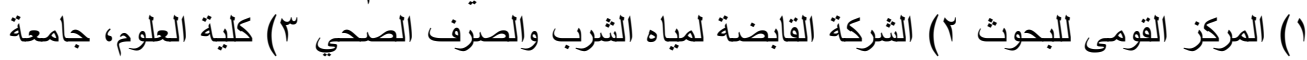
عين شمس

\section{المستخلصف}

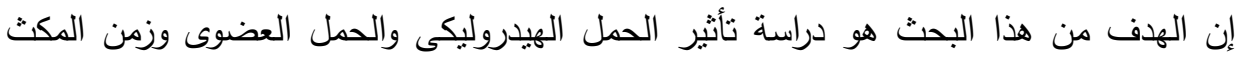

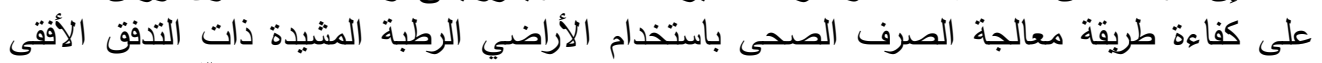

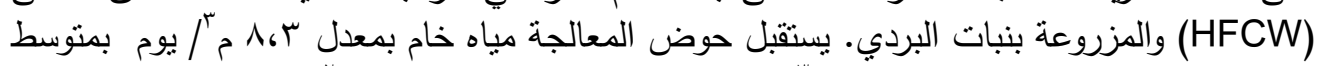

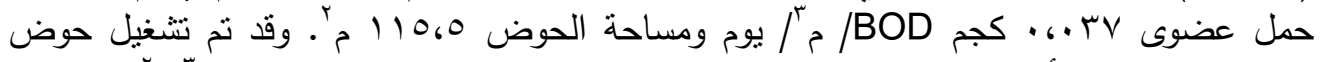

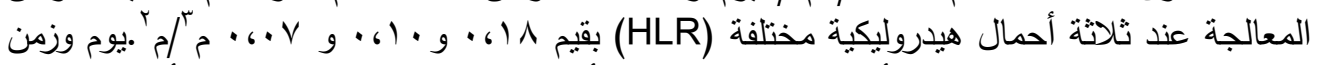

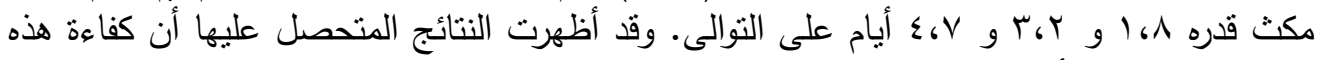

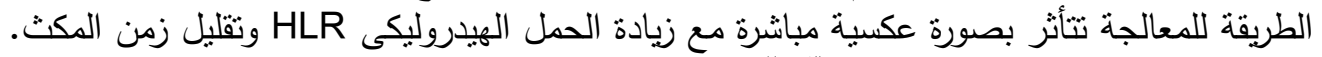

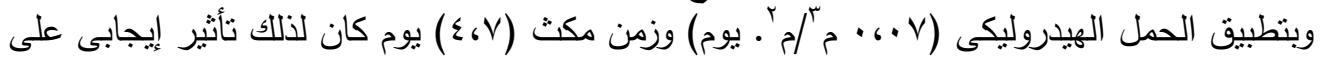

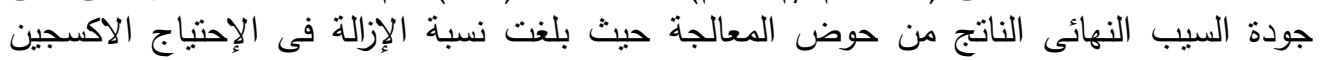
الكيميائي (COD)

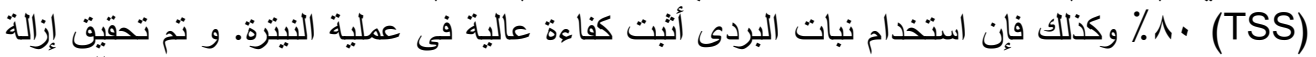

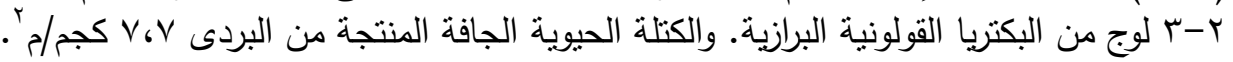

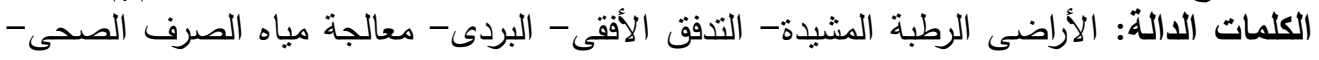

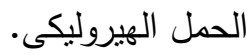

